(昭和 32 年 9 月 24 日受理)

繊維集合体の空吵分布の測定につルて

\author{
群需大学工学部 木下 茂 武 \\ 山形大学工学部 行 方 寅 次 郎
}

\title{
THE MEASUREMENTS OF PORE-SIZE DISTRIBUTION IN THE ASSEMBLY OF FIBRES
}

\author{
by Shigetake Kinoshita* and Torajiro Namikata**
}

(* Faculty of Engineering, Gumma Univrsity, Kiryu, Japan)

(** Faculty of Engineering. Yamagata University, Yonezawa, Japan)

The mercury-intrusion method for the study of pore-size distribution of porous materials was applied to assembly of fibres as such as woven fabrics and card slivers. In this paper, these determinations were made on various fabrics, compressed slivers and twisted slivers, at low pressure from $10^{-4} \mathrm{mmHg}$ to 2 atomospheric pressure in glass dilatometric apparatus. And the following results were obtained :

1. The three woven fabrics were selected for study of pore-size distribution. These fabrics were woven from $30 / 2$ 'S cotton yarns with same number of twist per inch. One of them was woven plain weave with loose thread counts, and another two fabrics were woven twill weave closely (Table I). On the relation between pore-size distribution and thread counts in fabrics, a shift of the distribution curve peak to smaller pores was observed as the thread count was increased. (see Fig. 4)

2. The compressed card slivers were selected for the study of dependency af bulk density on the pore-size dististion. These slivers were composed of $2 \mathrm{~d}$, viscose rayon filaments and their linear density was 0.04 grams per $\mathrm{cm}$. The pore-size distribution curves obtained for five sliers with various compression ratio, as shown in Table II, indicate that a shift of the distribution curve peak to smaller pores was observed as the compression ratio was increased (see Fig. 6).

3. The determination of pore-size distribution curve was selected for five slivers in various twist number per $\mathrm{cm}$. On the relation between pore-size distribution and twist number per $\mathrm{cm}$ in sliver, the pore-size distribution curve indicated that a shift of the distribution-curve peak to smaller pores was observed as the twist number was increased (see Fig. 9).

(Received 24.9. 1957)

\section{1. 緒蓑}

綫維集合体すなわり蟣維束, 糸、織物などの有孔性は被 服の雨気性，保温性などを決定する重要な因子である。

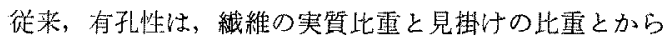
含敘率として表示されているが，ここでは更にをれを絶 対的な細孔半征と，その分杵に上つて步示しようと試子 た。その基礎としては，い放るる多孔性物質，例えば素

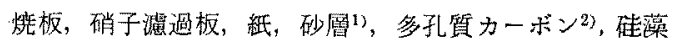
土, 酸性白土，乾燥剂引などの細孔半径扎よびその分布 北関する研究があり，ての応用として織布に括ける細孔

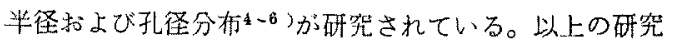

にはそれでれ長所，欠点を有するる，われわれは特心 Washburnの原理にもとずいた Ritter-Drake ${ }^{3\rangle}$ の水銀 㨉入法を用い，これを若干修正して、はじめ布帛密度の差 による細孔半径执よび孔径分布の変化の状態を実験し， さらにスライバーの环樎率和よび然数の变化にともなう 細孔半径拉よ゙孔径分布の変化について実験した。

\section{2. 実験装置と実験方法}

Ritter-Drake ${ }^{3)}$ によれば細孔半径和よび孔径分布に関 する理諭式は次の通りである。

すなわち，細孔に水銀を押込むに必要な圧力 $p$ と䋖 孔半径 $r$ との関倸は 


$$
p r=-2 \sigma \cos \theta
$$

である。ここにのは水銀の表面張力、日は接螌角である。

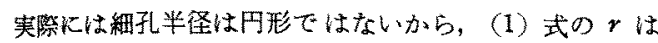
有効半径と考えてよい。

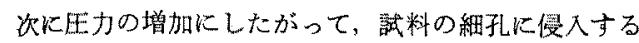
水銀の累㧼体積を $d V,(r, r+d r)$ なる䈥团の組孔半径 女存する孔の全体筫を $D(\boldsymbol{r}) d r$ と机ば，(1) 式上り分 布函数

$$
D(\boldsymbol{r})=\frac{p}{r} \cdot \frac{d(\Delta V)}{d p}
$$

をうる。実験的に $D(\boldsymbol{r})$ を定めるには (2) 式の $\frac{d(\Delta V)}{d p}$

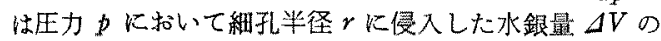

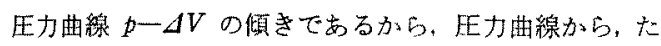
代らに求めることが出来る。

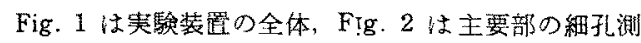

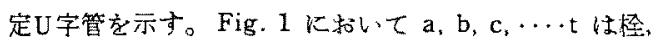
A.C は空気濯, $\mathrm{M}_{1}, \mathrm{M}_{2}$ はマノメータ，P*S は测定U字 管，P.Gはビラニ・ダージ，M.Gはマクレオード・ダー ジ，G・P はガイスラー管，D.P は昖教ポンプ， R.P は
回転ポンプを示す。細孔测定U字管は Fig.2 に示すご

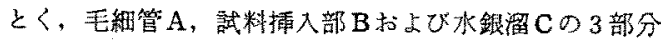
がらなり，柽 a，b，c，d，eを有し，管Dは回転ポンブ， 筧Eは桩散ポンプ，管Fは努気留にそれぞれ連絬されて いる。管 Gは従来の文献4ー6)のbのに多少修正を施した るので，B内部の真空度を良くするために取付けたもの である。毛細管A のを用いた。B内の寸法は报およそ内径 $22 \mathrm{~mm}$, 高さ $20 \mathrm{~mm}$ でる。

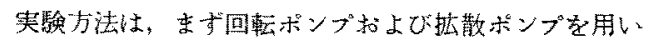
て、管I内を真空にしてから，栓 1 を開いて水銀溜内の

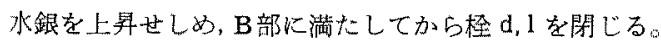

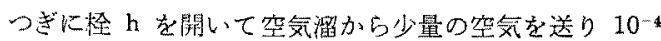

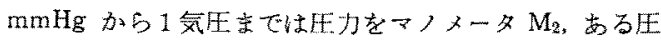

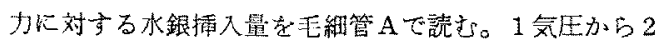

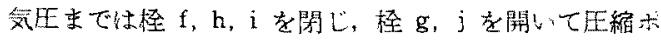

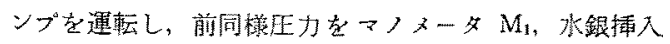
琵を气細管Aで讜みとる。

㬰験は最初，細孔测定U字管に試料を入れない場合， 水銀が侵入するか，しないかを碓かた。その結 果，我銀が侵入することが解つたので，試料の

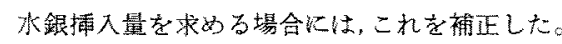
実験は空の場合も，試料を入れた埸合む，3〜5

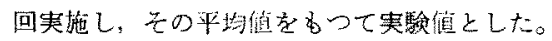

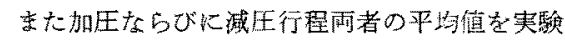
値とした。実験は玨力 $10^{-4}$ から $100 \mathrm{~mm}$ 水銀 王の低王範围に和いて行つた。

賏美の原因としては，まず，水銀插入墨の温

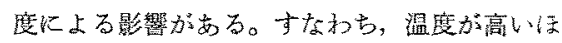

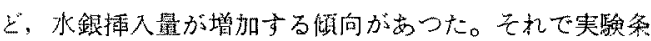

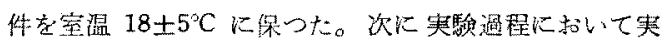

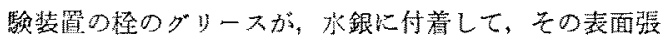

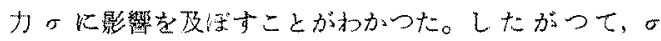
の倠はグリースで污れたもの登採つた。

\section{3. 布の場合の測定例}

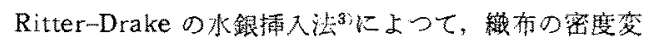

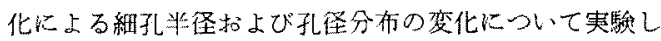

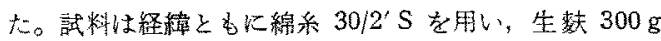

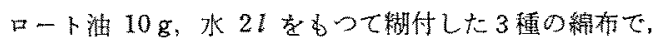
その性筫を第I表に示した。

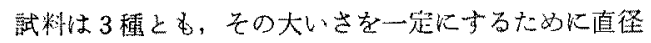
$21.3 \mathrm{~mm}$ のポンチ状刃物で划拻いて用いた。試料を安 定にするために，Fig. 2 に示すごとく多数の扎を崈つ た円形セルロイド板Hを用いた。試料は 3 枚のセルロイ ド板に挾及，Fig.2のB部に入れ䒸Kをして，前述の方

Fig. 2 Part of measuring equipment 
TABLE I Properties of Fabrics.

\begin{tabular}{|c|c|c|c|c|c|c|}
\hline $\begin{array}{l}\text { Fabric } \\
\text { Number }\end{array}$ & state & weave & $\begin{array}{c}\text { Thread count } / \mathrm{cm} \\
\text { warp } \times \text { Filling }\end{array}$ & $\begin{array}{l}\text { Weight } \\
\left(\mathrm{g} / \mathrm{cm}^{2}\right)\end{array}$ & $\left|\begin{array}{c}\text { Thickness } \\
(\mathrm{mm})\end{array}\right|$ & $\begin{array}{l}\text { void space } \\
\text { (cc/g) (dry) }\end{array}$ \\
\hline I & Grey & Plain & $18 \times 20$ & 0.0175 & 0.45 & 2.097 \\
\hline II & $\prime \prime$ & Twill $(1 / 7)$ & $23 \times 23$ & 0.0186 & 0.60 & 2.782 \\
\hline III & $\prime \prime$ & " $(2 / 6)$ & $24 \times 24$ & 0.0196 & 0.65 & 2.866 \\
\hline
\end{tabular}

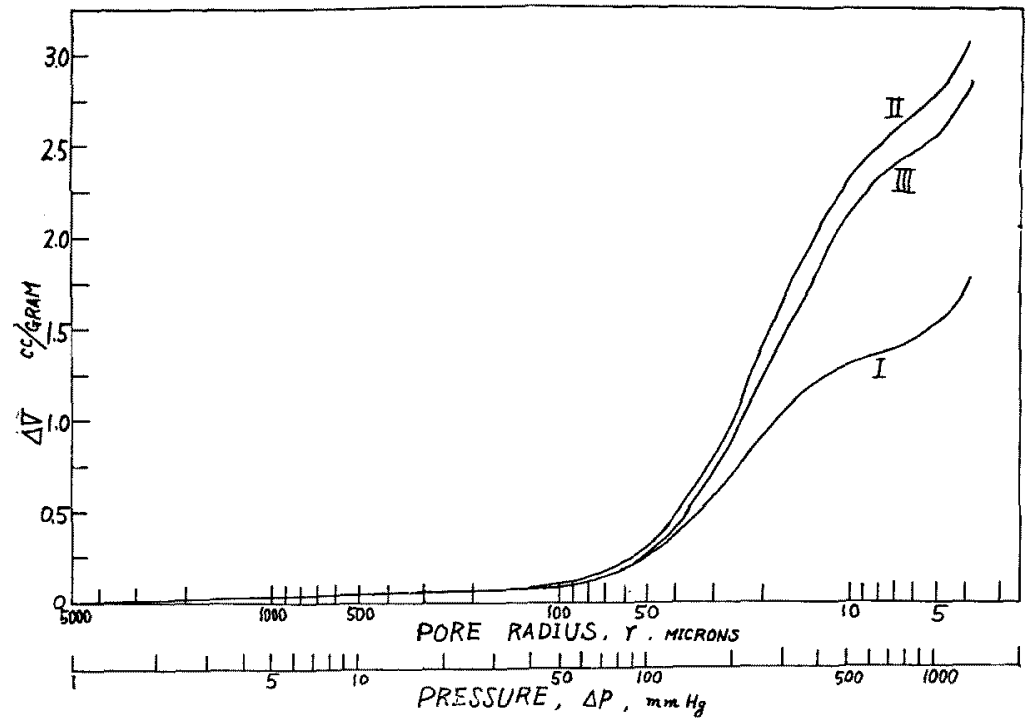

Fig. 3. Pressure curves for various fabric
半径 (ミクロン) を片対 数図でてた。

実験は低生範国内で行 われたので,この範閏内 では絊布を構成している 系相互間の細孔分布を利 るにすぎながつた。る曲 線と古真空状態で性全く 水銀の侵入が認められな いが, $1 \mathrm{~mm}$ 水銀仕火至 って僅か深入し，100 $\mathrm{mm}$ 水銀圧飞扣いて急增 し，400または $500 \mathrm{~mm}$ 水鉩圧に扣いて稍停滞 ᄂ, $1000 \mathrm{~mm}$ 水銀压に求 いて再び急增した。平織 物と斜文織物とを比䩙し て見ると，前者は後者に 比ベて, 圧力の低い点に 扣いて增加力を減じてい るし，また插入水銀量が 少なかつた。これは密度 の差による細孔量の差㦈 上るるのと考它ら机。

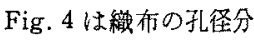
法によつて実娩した。

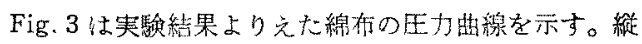

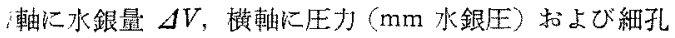

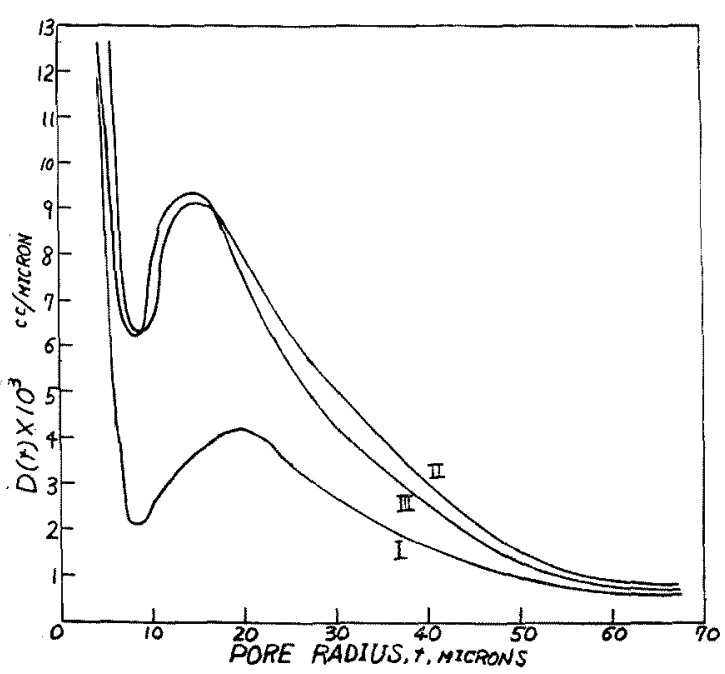

Fig. 4 Pore-size distribution curves for various fabrics
布䀑線を示す。縦軸比分布函数 $D(r)$ を $1 \mathrm{~g}$ 当りの值 で示し，槛軸に細孔半径 $r$ を示した。図に叔て曲線

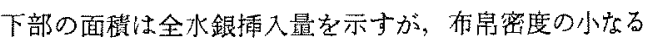
平織物は，布帛密度の大なる斜文織に比べてその眭が 小である。また 3 曲線の頂点は，それでれの試料の持

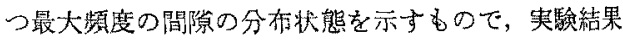
から平織物の最大頻度間隙が斜文繊物の最大頻度間裳 に比べて大なる細孔半径を有していることが知られ る。なお 3 曲線とも，細孔半径 $5 \mathrm{~mm}$ 以下飞和以て も5120頂点を有することが考克られるが，これ恬 系相互間の案陵を完全に満たした水銀が任力の增加と

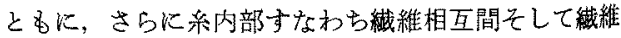

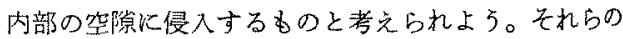

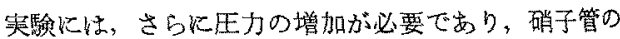
測定装置では不可能であり，相当の高生にす酎穴る金 属筫の测定装置が必要なことは Ritter-Drake ${ }^{\text {s) }}$ の教 えているとこうである。

\section{4. スライバーの匡縮率と空隙分布}

供試材料として，日東紡簤株式会社郡山工場製のス ライバーを用いた。その単絾維の緎度は $2 \mathrm{~d}$ ，スライ 


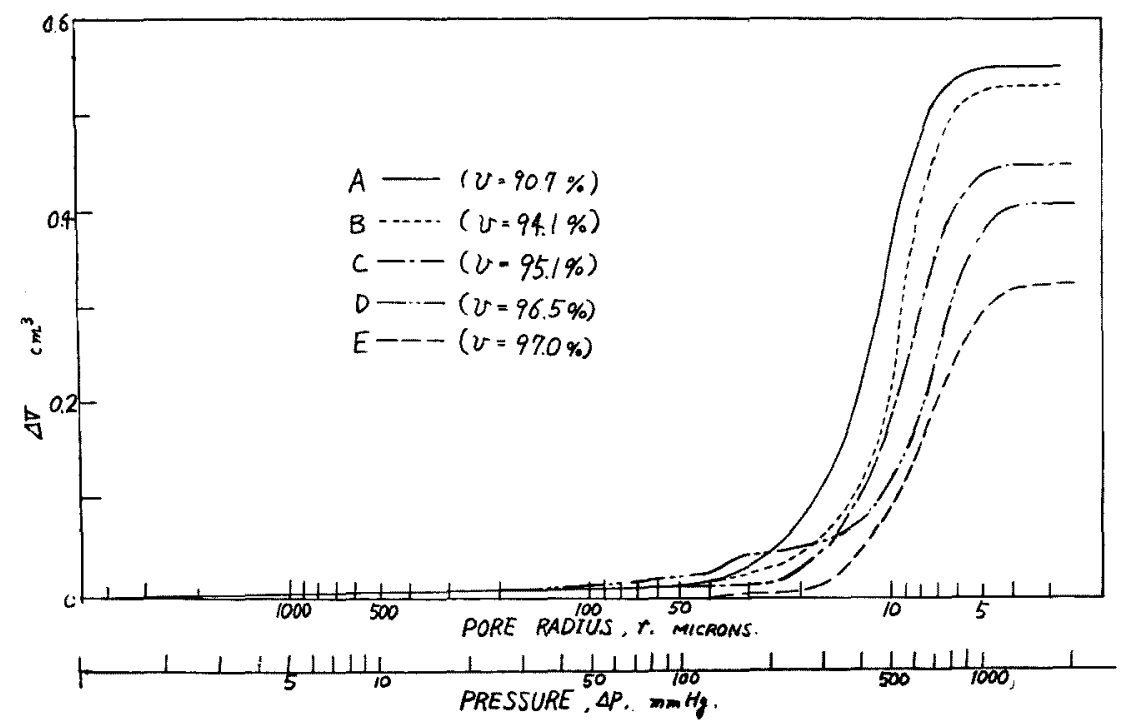

Fig. 5 Pressure curves for compressed sliver

旃の線密度は $0.04 \mathrm{~g} / \mathrm{cm}$ であった。

試料は $2 \mathrm{~cm}$ 長さに切断し, 適宜横力向から 正縮できるホールダに㨂入，これを細孔测定U 字管のB部に入れて笑騒した。スライバの状態 屾第功表の通りである。

な怙，压穛深 $v$ ならびに見かけの比重 $\rho_{v} に$ 泩次式を用いた。

$$
v=\frac{V_{0}-V_{1}}{V_{0}} \times 100(\%)
$$

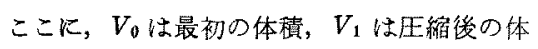
耫を示す。さた，

$$
\rho_{v}=\frac{W}{V_{1}} \quad\left(\mathrm{~g} / \mathrm{cm}^{3}\right)
$$

ここK, $W$ は試料の重量を示す。

Fig. 5 は 5 種類のスライバーの圧縮率を変化 せしめた場合の王力曲楾を示す。各曲線とも $100 \mathrm{~mm}$ 水銀生までは, 㴗之んど水銀の侵入が

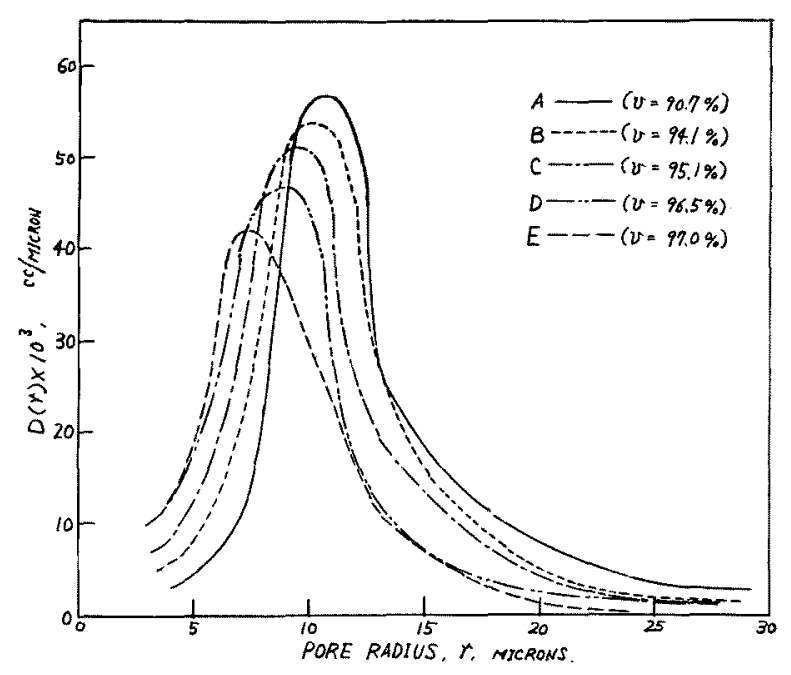

Fig. 6 Pore-Size distribution curves for compressed sliver
見られないか，200 300 $\mathrm{mm}$ 水銀圧に括いて水銀掅入 量を急增し，1000 1500 $\mathrm{mm}$ 水銀圧に抢いて略水平々 なる。曲線が水平になったことは，水銀の擂入する啶隙 がなくなつたことを示す。その時の $\Delta V$ ほ圧樎率の大 なる琵小となつている。これは压縮婆を增すことによつ て空隌が威少していることを示すすのである。

Fig. 6 は扎径分布曲線を示す。曲線は孔径 4 !位で 急に上畀し， $D(r) 42 \sim 57$ を頂点として，下降し，孔径 $25 \sim 30 \mu$ で略横軸汇平行となる。各曲線の媔点は，圧縮 率が增すにしたがつて，孔径の小なる方に移動し，その 最大犆も減少している。このこと性压縮率の增加化よつ
て，空陌が小となり，また全空隌体稹も隇少することを 示したものである。

スライバ一の生樎倳 $v$ による空隙体稍 $\Sigma \Delta V$, 最大

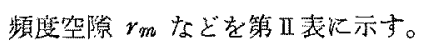

また，Fig. 7 Kスライハの見かけの密度 $\rho_{v}$ と全空

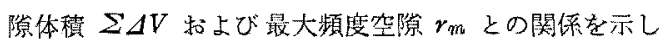
た。

\section{5. スライパーの撚数と空隙分布}

前同様のスライバーを加然し，これをそのまま適当の ホールダに摤み，細孔測定U字管のB部に挿入し，前同 
TABLE. II Properties of Compressed Sliver

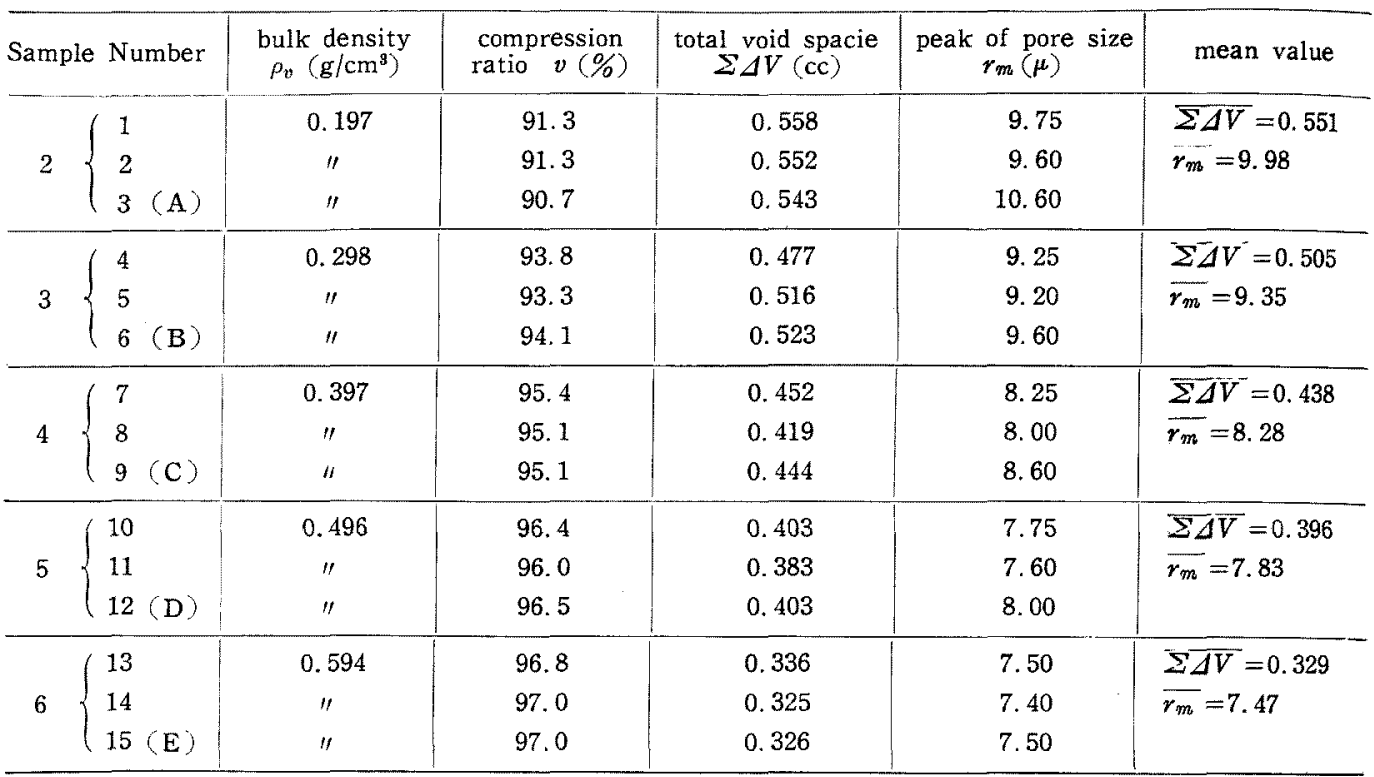

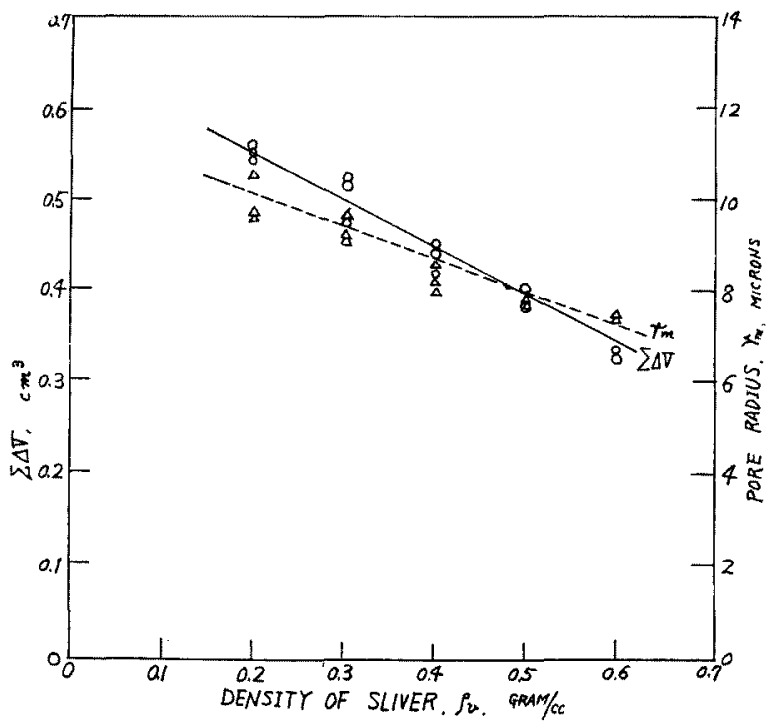

Fig, 7 Relations of Pore--Size and sliver density

TABLE. III Properties of twisted Sliver

\begin{tabular}{c|c|c|c|c|c}
\hline $\begin{array}{c}\text { Sample } \\
\text { Number }\end{array}$ & $\begin{array}{c}\text { Length } \\
(\mathrm{cm})\end{array}$ & $\begin{array}{c}\text { Diameter } \\
(\mathrm{cm})\end{array}$ & Twist/cm & \multicolumn{2}{|c|}{ Void Space (cc) } \\
\hline A & 1 & 1.230 & 0 & 0.437 & 0.210 \\
B & $\prime \prime$ & 0.546 & 0.5 & 0.087 & 0.137 \\
C & $\prime \prime$ & 0.386 & 1.0 & 0.091 & 0.174 \\
D & $\prime \prime$ & 0.316 & 1.5 & 0.053 & 0.109 \\
E & $\prime \prime$ & 0.270 & 2.0 & 0.031 & 0.027 \\
\hline
\end{tabular}

様に実䁩した。実験結果を第且表に示した。

Fig. 8 は压力曲線，Fig. 9 は分有曲線を 示す。Fig. 8 に示す如く，撚数が增加するに したがつて，水銀插入量が漱次滅少する傾向 がある。

B と Cが例外なのはホールダの㨡みを補正 できなかつた愦差と考えられる。

Fig. 9 において, 各曲線の頂点が, 撚数の 增加するにしたがつて，漸次小なる細孔半佳 の方へ移る佰向があるのは，然数の增加炕 って，空隚が小さくなるためと考克られる。

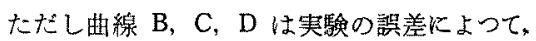
適包な絬果を学られなかつた。

また第而表は撚数と空隙量の理論ならびに 実娩值を示したるのである。理論値は撚数

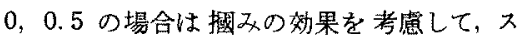

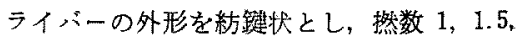
2.0 の場合恃筒状として計算したもので女 る。実験の精度から両者の完全な一致を認め ることは出来なかつた。

\section{6. 結 論}

Ritter-Drake の水銀挿入法を用いて，緎 維集合体の空幥分布の測定，すなわら布帛密 度の差による細孔径分布の変化ならびにス ライパーの王樎率扎よび撚数の变化化伴う孔 径分布の変化について実験し次の結果を克 


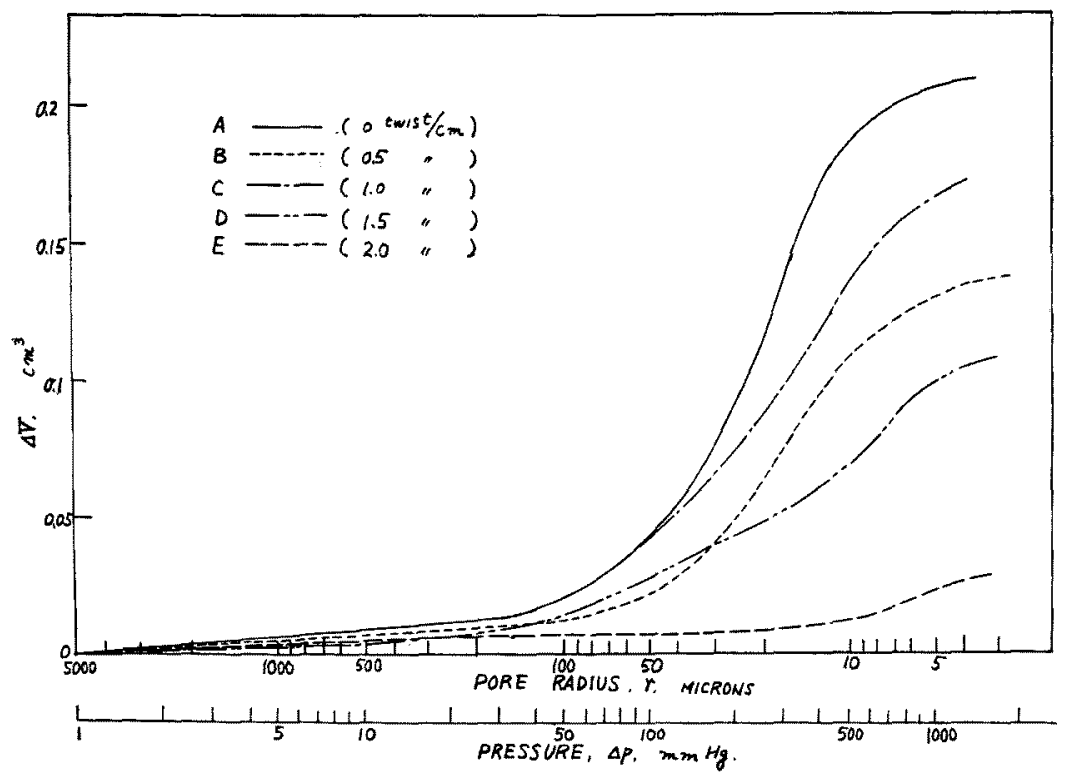

Fig. 8 Pressure curves for twisted sliver

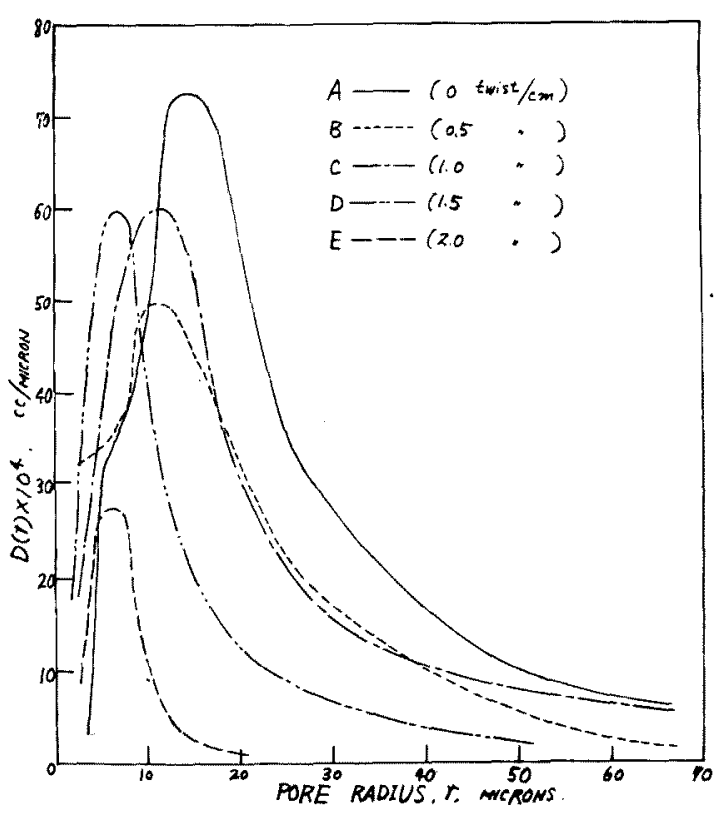

Fig. 9 Pore-size distribution curves for twisted slive: た。

（1）布帛密度の差による孔径分布の変化については 布帛密度を增すにしたがつて，孔径分布曲線の頂点は小 なる細孔半径の方へと移動した。

（2）スライパーの圧縮率の差による孔径分布の変化
に関しては，生縮染を堌加するにしたがつて，細孔 が押しつぶされて小さくなって行くことが解つた。

(3) スライパーの然数の差に上る孔径分布の变 化に関しては，然数を增加するにしたがつて，分布 曲楾の頂点が小なる細孔半径の方へ移動し，撚数の 增加によつて細孔半堡が小さくなって行くことが解 D大。

本実験は昭和 30〜31 年頃行つためのををとめた あので，本実娩に協力をいたたいた鈴木孝三，千喜 良昭三，辛野行一，遠藤公夫の各氏に打礼申上げる。 なた終始鞭澾を睗わつた吉田善一郎氏，助言された 堺越源一，山口博司の各氏に衾心より深甚の謝意を 表する。

\section{文献}

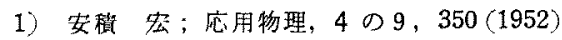

2)福田義民. 河添邦太郎; 生産研究, 4, 228 (1952)

3) Ritter, H. L., \& Drake, L.C. ; Ind. Eng. Chem., Anal. Ed., 19, 782, 787 (1945)

4) Burleigh, E.G., Jr., Wakeham, H., H, Honold, E., \&Skau, E. L.; Text. Res. J., 19, 547 (1949)

5) Wakeham, H. \& Spiecer, N. ; Text. Res. J., 19, 703 (1949)

6) Honold, E \& Skau, E. L. ; Text. Res. J., 21. 419 (1951) 